\title{
Indonesia is exploiting the COVID-19 crisis for illiberal
}

\section{purposes}

Edition 2, 2020

Rafiqa Qurrata A’yun, Abdil Mughis Mudhoffir

DOI: 10.37839/MAR2652-550X2.6

Novel coronavirus disease (COVID-19) has become a test for many nations in relation to the way they respond to the outbreak. Most governments around the world have dramatically increased their powers to deal with the crisis. Some have been successful in controlling the outbreak and protecting citizens' rights, such as New Zealand and Germany. Indonesia has failed at both.

In an illiberal democratic country such as Indonesia, the crisis has become a means for elites in politics and business to further accumulate power and money. Indonesia's illiberal nature - characterised by the relative absence of the rule of law and pervasiveness of corruption - has made it possible for dominant interests to exploit the crisis instead of addressing it for the general good.

Indonesia's handling of the COVID-19 has been the worst in Southeast Asia. A good indication of this is that its mortality rate is approximately 7 percent, the highest among other countries in this region, which are mostly around 0-3 percent.

This is not simply a result of the leadership style of the President Joko Widodo (Jokowi), who has been slow to respond and has displayed a lack of strategic thinking, as many have argued.

Indonesia's failures go much further: the unwillingness of the government to deliver 
social security to those in need, the suspect use of the COVID-19 relief fund, little accountability in relation to the use of COVID-19 related money; and politicobusiness elites using the crisis as a chance to pass many controversial proposed laws that give more power to the state and open the way for further plundering of state resources.

\section{Unwillingness to deliver social security to those in need}

On March 30, President Jokowi announced large-scale social restrictions (PSBB) that would be coupled with "civil emergency" policies to enforce a lockdown to slow the spread of COVID-19. While a civil emergency has not officially been enacted, it remains an option for the government if it believes the existing PSBB status is not working well enough.

Declaring a civil emergency hugely increases the government's powers and suspends normal rules. Advocacy groups, fearing abuse of power, have argued a civil emergency status is not necessary and that existing laws on disaster mitigation and health quarantine are sufficient.

The government's motives look suspect because under existing health quarantine laws (Law No. 6 of 2018 on Health Quarantine), by applying territorial quarantine (lockdown) the central government would have had to deliver social security payments. Yet there is no such obligation on the government when PSBB is applied, or if civil emergency status is in force.

Furthermore, the government's claims that it has increased spending on the poor due to COVID-19 are misleading. Jokowi has declared that his social safety net worth \$US7.9 (IDR 110 trillion), and which includes the family hope program (PKH), the staple food program, pre-employment cards and free electricity - represents an increase in aid for poor families as part of COVID-related responses. 
Jokowi claimed on March 31 that the government had increased the number of recipients of the PKH program from 9.2 million to 10 million households and the amount of cash assistance by 25 percent.

However, more than a month earlier when the government was still claiming Indonesia had no COVID-19 cases, the Social Affairs Ministry made a very similar statement about PKH figures: that the budget for PKH targeted at poor households with children and/or pregnant women had been increased by 25 percent. The President Regulation No. 61/2019 on the 2020 Government Action Plan also stated that the number of PKH recipients had expanded from from 9.2 million to 10 million households.

Except for free electricity, the amounts for social safety net programs were all allocated before the outbreak. Jokowi's claim of extra COVID-19 spending is misleading and likely intended to boost his popularity amid public disappointment in his handling of the outbreak.

\section{Government elites with conflicts of interest}

At least two president special staff members are known to have been involved in conflicts of interest between their public roles and private interests in relation to COVID-19 relief funds.

One of the government programs that provides online training for laid-off workers amid the pandemic, for example, has appointed an education start-up company Ruangguru, whose CEO is a presidential staffer Adamas Belva Syah Devara.

The appointment of Ruangguru was made without a bidding process, as admitted by the Deputy Minister for the Coordinating Ministry for Economic Affairs, Rudi Salahuddin, who also said seven other companies were appointed without bidding due to time limitations. Dismissing bidding processes for projects of more than \$US14.3 thousand (IDR 200 million) - as these projects are - violates Presidential 
Regulation (Perpres) No. 16/2018 on government procurement.

However, Devara has defended the process, saying he played no part in any decision-making in the appointment of Ruangguru as a government partner and that there is no conflict of interest.

Further, the timing and content of the online training programs such as the one run by Ruangguru program are suspect. Devara has stated that the selection process to implement the program was begun in December 2019 - well before the COVID-19 outbreak. The companies are providing something that is freely available elsewhere: similar online training content can be watched freely in YouTube channels; and the online training offered does not address the basic needs of the laid-off workers, like how to apply for new jobs. According to labour unions, what unemployed workers really need is social aid.

Another president's staffer, Andi Taufan Garuda Putra, has also been accused of a conflict of interest after sending a letter to district heads on official government letterhead, requesting that they support a COVID-19 relief program led by a company he owns, Amartha Mikro Fintek.

\section{There's little accountability in terms government COVID-related expenditure}

The government's COVID-19 pandemic response also gives it excessive power over the nation's budget. Everything spent by the government in relation to COVID-19 is considered as a measure to secure the economy from the crisis. No decisions made or actions taken can be filed at a state administrative court and government officials are immune from being criminally charged.

This situation is made worse by the weak anti-corruption body, the Corruption Eradication Commission (Komisi Pemberantasan Korupsi, KPK), which was weakened further by the revision of KPK Law in September 2019. Civil society has 
doubted the capacity of this body to monitor and investigate irregularities regarding COVID-19 expenditure.

\section{Critics of the government are being arrested}

On April 23, Ravio Patra, an activist who has been critical of how the government has managed the outbreak, is one example. The police accused him of provoking nationwide riots through a Whatsapp broadcast.

Rights activists claim that the broadcast was made when his phone was hacked. They've raised as significant the fact that Patra had publicly criticised one of Jokowi's staff, Billy Mambrasar, for alleged conflict of interests in implementing government projects in West Papua. Our interviews with activists suggest that Patra's criticism of Mambrasar was a reason he was arrested. Some activists believe that Mambrasar has a close link to Budi Gunawan, the head of Indonesia's national intelligence body.

Several other people from different regions have also been arrested, mostly because of their comments on social media in relation to the way government has responded to the COVID-19 outbreak. Charges include insulting the President and spreading hate speech. KontraS, an Indonesian human rights watchdog, reported that as of April 8 there were four cases of people from different regions (Jakarta, Riau and Central Java) being charged with insulting authorities.

Such arrests were common even before the COVID-19 outbreak, mostly under the Electronic Information and Transactions Law (UU ITE). Amnesty International has noted that during Jokowi's first term (2014-19) there were at least 203 criminal investigations against those who criticised the government. COVID-19 has resulted in further opportunities for authorities to use this law to silence its critics.

Indonesian police may have stepped up their role in enforcing laws related to 
criticising the government. According to a leaked classified police telegram in April, the National Police chief Gen. Idham Azis called for police to monitor the "development of the situation and opinions [expressed] in cyberspace" in relation to the COVID-19 outbreak.

\section{Passing unrelated laws during the crisis}

The Jokowi administration and ruling parties in parliament (DPR) have exploited the outbreak to hasten the deliberation of many controversial proposed laws that could open the way for the government to extend its powers, with possible negative outcomes.

The Omnibus draft law on job creation (RUU Cipta Kerja) is one of the bills prioritised by the parliament to be legislated during the COVID-19 outbreak. The bill revises more than 80 existing laws to boost investment and simplify processes for business; and would further centralise authority in the Indonesian government. The government has cited the need to boost the economy amid the pandemic as the reason to push the bill through as quickly as possible.

However, workers' unions are concerned the bill reduces labour rights including those related to severance payments and compensation for laid-off workers. The bill will make criminal punishment for businesses violating environmental protections much lighter; remove building permits as one requirements to obtain a business license and significantly weaken responsibilities for environmental protections.

Responding to many critics, especially from labour unions, Jokowi claimed on April 24 that both the executive and legislative have agreed to delay the deliberation of this bill. But according to Willy Aditya, the Deputy Chairman of the House of Representatives' legislation body (Baleg), the House has never received any official government letter requesting a delay of deliberations. Jokowi's claim was likely motivated by avoiding labour demonstrations on May Day as well as gaining public sympathy. On April 27, the DPR continued to hold a virtual meeting discussing the 
bill.

The Criminal Code bill (RKUHP) is another controversial bill that may be pushed through parliament while the government has increased powers. It was opposed by the student movement last year due to concern about weakening of rights such as freedom of speech, by including crimes relating to insulting heads of state and the government. After a series of protests that left at least five students dead, the deliberation of this bill was halted, but now it has become one of the government's priority bills.

Another bill opposed by students last year was revisions to the 2009 Coal and Mineral Mining Law (RUU Minerba). Activists claims the revisions would protect corruptors, criminalise communities and endanger people and the environment. On May 12, the House of Representatives approved this controversial revision.

Moves on passing these laws have been made amid the prohibition on social gatherings, including demonstrations. Simply put, attempts made by the parliament (which is dominated by the ruling parties) to hasten the enactment of these bills during the pandemic are a means to override public concern.

\section{Jokowi and his political and business supporters don't take the crisis seriously}

So far, many observers have attributed Indonesia's failure in handling the COVID-19 outbreak to Jokowi's incompetence and lack of strategic thinking. Many government officials were in denial over the virus and have not delivered effective responses to the outbreak. But this is not simply a case of incompetence.

Focusing on the incapacity of the government obscures Indonesia's illiberal nature. We need to see the problem beyond the leadership style of the current government. Bad governance and institutional weakness have long been entrenched in Indonesia, and the mess in dealing with the outbreak is better viewed as a consequence of 
Indonesia's illiberal political and economic system.

Within this context, many politico-business elites tend to view the mess as an opportunity to further their interests and increase their power and material resources. They have exploited the crisis for illiberal purposes and ignored the most vulnerable.

Rafiqa Qurrata A'yun is a Lecturer at the Faculty of Law at the University of Indonesia \& a PhD student at the Melbourne Law School. Abdil Mughis Mudhoffir is a Lecturer in the Department of Sociology at the State University of Jakarta \& postdoctoral research visitor at the Asia Institute, University of Melbourne.

Related webinar: Governance or social resilience: Learning from Southeast Asia's experience with COVID-19.

Image: Indonesian police officers wear personal protective equipment amid the COVID-19 outbreak. Credit: Herwin Bahar/Shutterstock.

This article was amended on May 19 to correct a claim about the Omnibus draft law and environmental protections. 